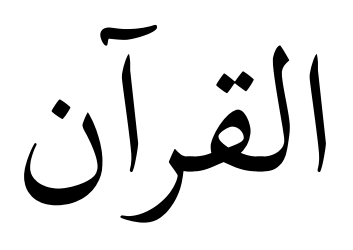

\title{
The Quran
}

\section{Key Words in Context}

Adjectives, Nouns, Proper Nouns and Verbs

$$
\mathrm{J}-\mathrm{R} / \mathrm{C}
$$

Elie Wardini 
Gorgias Press LLC, 954 River Road, Piscataway, NJ, 08854, USA

www.gorgiaspress.com

Copyright (C) 2020 by Gorgias Press LLC

All rights reserved under International and Pan-American Copyright Conventions. No part of this publication may be reproduced, stored in a retrieval system or transmitted in any form or by any means, electronic, mechanical, photocopying, recording, scanning or otherwise without the prior written permission of Gorgias Press LLC.

2020

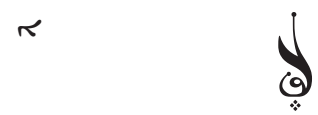

ISBN 978-1-4632-4148-3

\section{Library of Congress Cataloging-in-Publication Data}

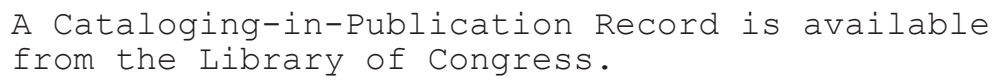

Printed in the United States of America 